\title{
Exceptional Chromosomal Evolution and Cryptic Speciation of Blind Mole Rats Nannospalax leucodon (Spalacinae, Rodentia) from South-Eastern Europe
}

\author{
Ivo Savić ${ }^{1}$, Duško Ćirović ${ }^{1}$ and Vanja Bugarski-Stanojević ${ }^{2, *}$ \\ 1 Biological Faculty, University of Belgrade, 11000 Belgrade, Serbia; \\ ir_savic@yahoo.com (I.S.); dcirovic@bio.bg.ac.rs (D.Ć.) \\ 2 Institute for Biological Research "Siniša Stanković", University of Belgrade, 11060 Belgrade, Serbia \\ * Correspondence: vanjabs@ibiss.bg.ac.rs; Tel.: +381-11-207-8331
}

Received: 30 August 2017; Accepted: 17 October 2017; Published: 25 October 2017

\begin{abstract}
Mole rats are exclusively subterranean and highly specialized rodents. Their long lifespans, remarkable anti-cancer mechanisms, and various distinctive adaptive features make them a useful research model. Moreover, opposing convergence of morphological traits, they have developed extremely high karyotype variability. Thus, 74 chromosomal forms have been described so far and new ones are being revealed continuously. These evolved during the process of rapid radiation and occur in different biogeographical regions. During research into their reproductive biology we have already provided substantial evidence for species-level separation of these taxa. Here, we review diverse chromosomal forms of the lesser blind mole rat, Mediterranean Nannospalax leucodon, distributed in South-eastern Europe, their karyotype records, biogeography, origin, and phylogeny from our extensive research. In the light of new data from molecular genetic studies, we question some former valuations and propose a cryptospecies rank for seven reproductively isolated chromosomal forms with sympatric and parapatric distribution and clear ecogeographical discrepances in their habitats, as well as new experimental and theoretical methods for understanding the courses of speciation of these unique fossorial mammals.
\end{abstract}

Keywords: karyotype evolution; chromosomal rearrangements; speciation; cryptic species; cytotypes; chromosomal forms; fossorial; underground

\section{Introduction}

With more than 2000 described species, rodents are the most abundant mammalian order, with $42 \%$ of its total species diversity [1]. Molecular phylogenetics and cytogenetics has enabled continuous growth in the number of newly discovered species, often revealing morphologically similar but genetically and/or karyotypically divergent cryptic species [2]. Chromosomal rearrangements (CRs) are frequent among rodents, especially in the two most species-rich families, Cricetidae and Muridae [3]. However, there is no default rate of karyotype evolution. While considerable chromosomal conservation was found in certain taxa (castorimorph and anomaluromorph rodents), some karyotypes of the myomorphs were highly reorganized [4-9]. Similarly, two genera of the Eurasian blind mole rat (BMRs), subfamily Spalacinae (Gray, 1821) ([1,10-15] and others): the greater BMR genus Spalax (Guldenstaedt, 1770) and the lesser BMR genus Nannospalax (Palmer 1903), have opposed rates of the karyotype change, i.e., highly conserved chromosomes and extensive karyotype variability, respectively. Nowadays many studies reach beyond standard research models, such as the mouse (Mus) and the rat (Rattus), in order to trace the evolution of crucial characters. Distinctive in many ways, BMRs have become a valuable research object, particularly because of their remarkable resistance to cancer and their longevity [16-20], besides other distinguishing features. These include tolerance to hypercapnia 
and hypoxia [20-24], a specific lipid profile [25] splice variants of heparanase unique in mammals, as well as particular expression patterns for p53 [26,27], circadian rhythms [28] sensory research [21]. In addition, cytogenetic analysis has revealed a distinguishing karyotype evolution [11,29-31].

Even though they are appreciated as a research object, BMRs are seriously endangered in their natural habitat, primarily because of an inappropriate conservation status, resulting from an unresolved taxonomy with an unrecognized species [1]. In the International Union for Conservation of Nature (IUCN) Red List of Threatened Species [32], only three species of BMRs are acknowledged and categorized as Data Deficient (DD). Many populations and species are therefore under serious threat, particularly due to the loss and fragmentation of their natural habitats [33,34].

Eurasian BMRs are typical residents of grassy steppes, hills, and mountain-meadows of the Eastern Mediterranean region, including Eastern and South-eastern Europe, Western Asia, and Northern Africa (Figure 1). They range in altitude from below sea level to an elevation of $2600 \mathrm{~m}$ above sea level (a.s.l.) $[1,35,36]$ and also inhabit cultivated areas, sparse woodlands, steppes, and mountain slopes, but do not occur in dense forests and marshy areas [10,13,35,37-40]. Spalacines are herbivores, eating mostly roots, tubers, rhizomes, and a little grass and grain. With subcutaneous vestigial eyes restricted to photoperiod perception, most of their lifetime is confined to underground tunnels [35]. They are chisel-tooth diggers, using their lower incisors for burrowing and the lower jaw as a shovel. Due to solitary, territorial, and aggressive behavior, their distribution is additionally fragmented [40]. The many adaptations necessary for living underground in cylindrical tunnels have defined their phenotype and obscured their actual phylogenetic relations. Thus, convergent morphology on the one hand and the intensive chromosomal speciation on the other tangle Spalacinae systematics and divide taxonomists since they were first discovered.

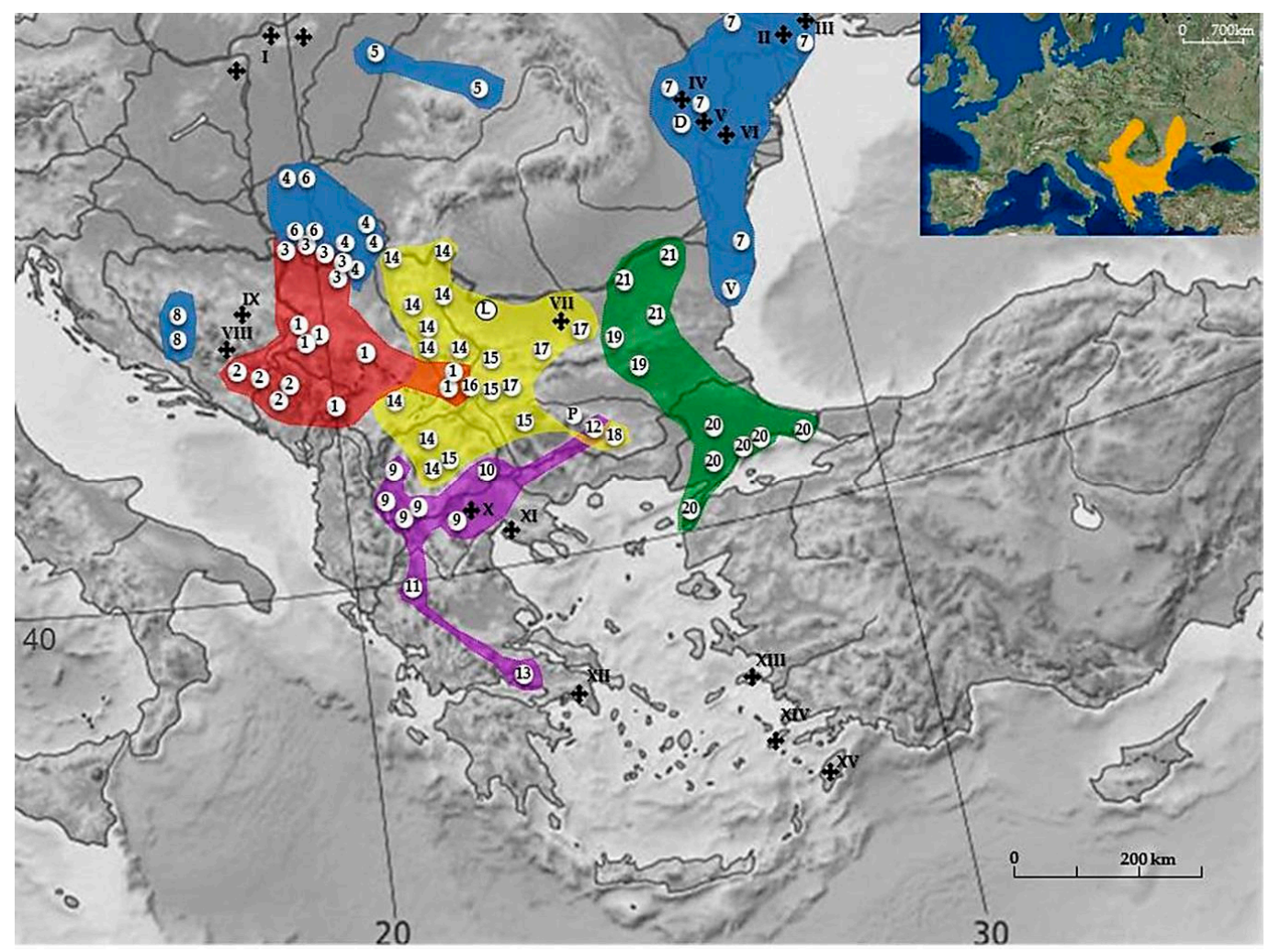

Figure 1. Geographic distribution of Nannospalax leucodon chromosomal forms (CF) from South-eastern Europe (reproduced with permission from [29], Figure 2, adapted). Red-the Yugoslav branch; yellow-the Serbicus branch; blue-the North Balkan subsidiary branch; violet-the South Balkan subsidiary branch; green-the East Balkan branch. Small map: N. leucodon distribution area from International Union for Conservation of Nature (IUCN) Red List of Threatened Species. For symbols see Table 1. 
Table 1. Chromosomal forms (CFs) and localities of recent and extinct Nannospalax leucodon from South-eastern Europe, as presented in Figure 1: (a) CFs grouped in four branches, following [29]; (b) fossil findings with localities.

(a)

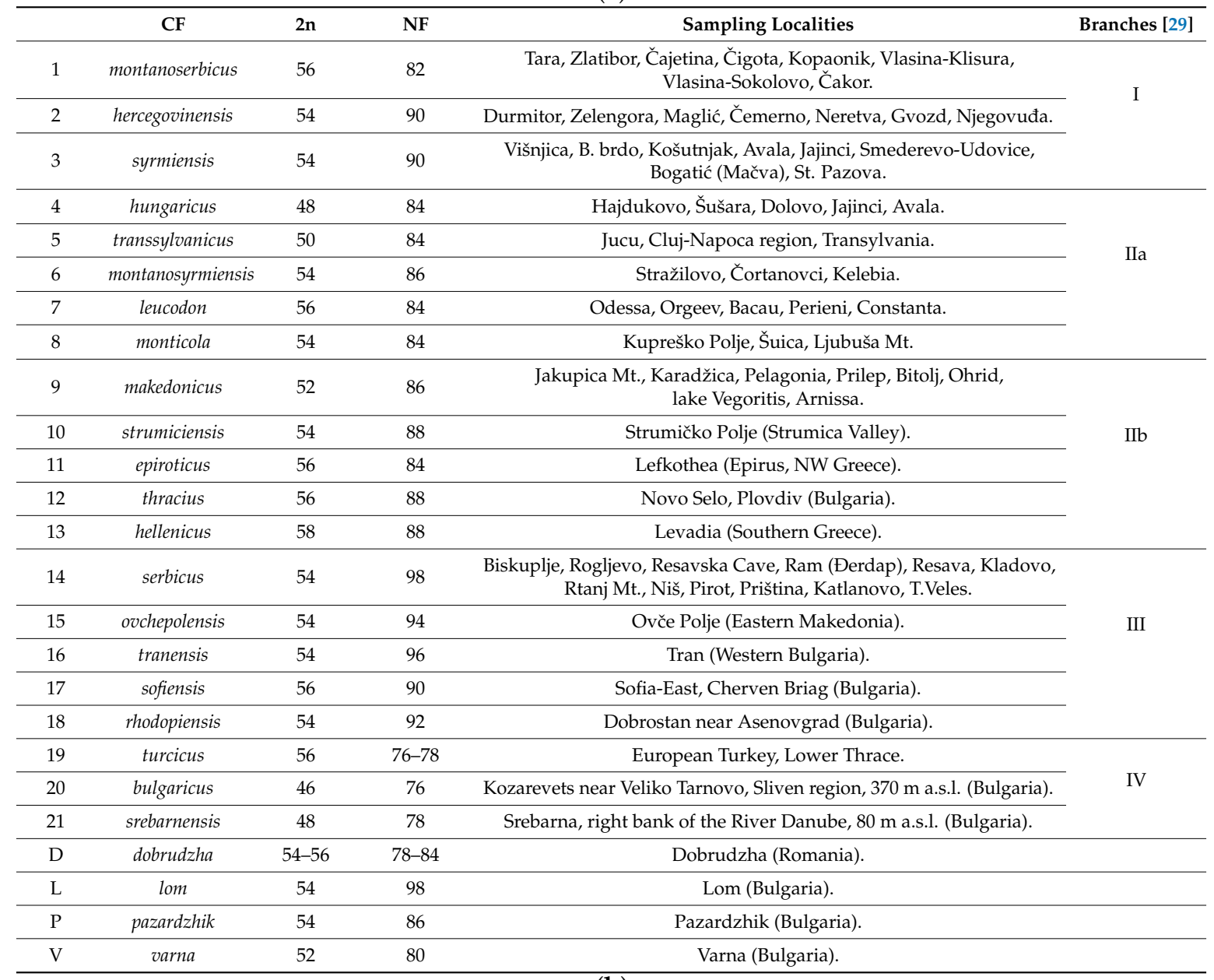

(b)

\begin{tabular}{ccc}
\hline & Fossil Findings & Locality \\
\hline I & N.cf. leucodon & West and North Hungary \\
\hline II & N. macoveii & Grebenniki \\
\hline III & N. odessanus & Odessa \\
\hline IV & N. macoveii & Berešti \\
\hline V & N. macoveii & Gavonosy (Gabanoasa) \\
\hline VI & N. macoveii & Malušteni \\
\hline VII & N. cf. leucodon & Golema Lisza peschtera \\
\hline VIII & N.cf. leucodon & Marinova Cave \\
\hline IX & Vetuspalax progressus & Banovići (BandH) \\
\hline X & Debruijinia kostakii & Karydia (Greece) \\
\hline XI & N. macoveii & Serrai \\
\hline XII & Pliospalax tourkobouniensis & Tourkobonnia Hill \\
\hline XIII & N.cf. nehringi & Chios \\
\hline XIV & N.cf. nehringi & Kalymnos \\
\hline XV & Pliospalax sotirisi & Maritsa \\
\hline
\end{tabular}

CF: chromosomal form; 2n: diploid chromosomal number; NF: fundamental chromosomal number; a.s.l: above sea level. 


\subsection{Phylogeny and Systematics}

The widely accepted classification [1] groups subfamily Spalacinae in the family Spalacidae, superfamily Muroidea, together with subfamily Myospalacinae (Lilljeborg, 1866), African mole rats Tachyoryctinae (Miller and Gidley, 1918), and Oriental bamboo rats Rhizomyinae (Winge, 1887), as reviewed in [29]. Despite the general convergence of morphological traits, members of the subfamily Spalacinae can be successfully distinguished morphologically from other subfamilies [41].

It was hypothesized earlier that the subterranean BMRs originated from a muroid-cricetoid stock in Asia Minor, or nearby, in the Lower Miocene (now Oligocene times) about 30-40 Mya, and adaptively radiated underground in the Balkans, towards the territories of Germany, Austria, Poland, steppic Russia, and the Middle East, as well as extending southwards to North Africa [35]. They have remained restricted to their current distributional range throughout their evolutionary history. Moreover, its area is being continually reduced, so the territories of present day Germany, Austria, Poland, Western and Central Hungary, Southern Greece, and the Aegean islands are now abandoned [35] (Figure 1). With changes of habitat in certain regions, especially recently due to anthropogenic effects, whole populations have disappeared (North-eastern Greece, some parts of Vojvodina, etc.) [42].

Numerous verifications of the presence of BMRs in the Balkans and Anatolia, throughout the entire Pleistocene [29], dating back to the lower Miocene [43], were recently updated. The genus Prospalax was placed in the family Anomalomyidae [44-46]. New data show that fossil records of the subfamily Spalacinae can be traced to the Late Oligocene of South-eastern Europe [44,47,48], but the group is probably much older. Currently, only four fossil genera are recognized: Vetuspalax [47]; Debruijnia [43]; Heramys [49] and Pliospalax (Kormos, 1932) = Sinapospalax (Sarıca and Sen, 2003) [44,47]. The oldest Spalacinae recorded so far is Vetusspalax progressus from the late Oligocene of South-eastern Europe, Banovići, Bosnia and Herzegovina (Figure 1) [47].

\subsection{Speciation}

Taxonomy below the subfamily level follows two different concepts: a mono-generic model $([1,35,40]$ and others) and a two-generic model of the large and small-bodied BMRs, based on morphological and karyological characteristics [10-13,41]. The taxonomic distinctiveness of these two genera and their monophyletic background is supported by recent molecular evidence $[15,42,50]$. Though highly similar, the greater BMR genus Spalax (Guldenstaedt, 1770) can be distinguished from the lesser BMR genus Nannospalax (Palmer, 1903) [12] by substantial morphological differences [10], which are used for fragmentary fossil material as well [47]. Moreover, these morphological characteristics evidently correlate with their different cytogenetic strategies [15].

\subsubsection{The Greater BMR Genus Spalax}

This genus includes large-bodied species with karyotypes characterized by the slow rate of chromosomal changes, a high diploid chromosomal number ( $2 n)$, and a fundamental chromosomal number $(\mathrm{NF})(2 \mathrm{n}=62 / \mathrm{NF}=124$, with the single exception of $S$. microphthalmus $2 \mathrm{n}=60 / \mathrm{NF}=120)$ and all bi-armed autosomes. These species have been recognized so far by their external, cranial, and dental characters [14]. Interestingly, even with massive geographical barriers between morphologically and/or cytogenetically differentiated Spalax species, they share similar morphology and identical $2 \mathrm{n}$ and NF with proportionately smaller interspecific differences in karyotypic structure [35]. This indicates that the 62 chromosomal forms (CFs) of blind mole rats had wider ranges in the past and that their karyotypes are relatively stable [51]. Six Spalax species are acknowledged: S. graecus (Nehring, 1898), S. arenarius (Reshetnik, 1938), S. microphthalmus (Güldenstaedt, 1770), S. giganteus (Nehring, 1898), S. uralensis (Tiflov and Usov, 1939), and S. zemni (Erxleben, 1777) [1]. Separation of additional species from S. graecus in Romania, namely S. antiquus (Méhely, 1909) and S. istricus (Méhely, 1909), has been proposed based on mitochondrial DNA (mtDNA) sequences and detailed anatomical comparisons [52]. 


\subsubsection{The Lesser BMR Genus Nannospalax}

The genus Nannospalax (Spalax typhlus leucodon Nordmann, 1840. Type loc. Near Odessa, Ukraine) consists of small-bodied species with karyotypes characterized by lower diploid numbers with many acrocentric chromosomes and by a proliferating chromosomal speciation observed in the extant species [10,11,29]. Moreover, among the 26 genera of Palaearctic mammals, this genus has the highest karyotype variability [6]. Species and populations of Nannospalax exhibit significant $2 \mathrm{n}$ and NF diversity, but it is still not clear which events shaped the extant karyotypes.

Species with low mobility generally have genetically more isolated populations [51] and consequently many cryptic species with a specific karyotype set, as observed in fossorial rodents. Indeed, rapid chromosomal evolution within and between populations and species are most commonly explained as specific adaptations to the underground way of life, low dispersal rates, fragmentation of the distribution range, and isolation of individual populations $[11,13,35,53]$. This arouses an important question regarding the mechanisms responsible for the completely different strategies in chromosomal evolution in Spalax and Nannospalax [15,50,52], as they share highly similar morphology, life style, and ecology.

The proliferating chromosomal speciation of the lesser BMR has brought confusion since the earliest discoveries. Spalax (= Nannospalax) leucodon was first described for a specimen from the Caucasus $2 n=48$ [54], then for one female from Bulgaria $2 n=54$ [55]. Detailed analysis of karyotypes from Deliblatska Peščara and Vlasina Lake, Serbia, suggested that two forms separated by the River Danube may exist [4]. The complex question of the taxonomy and the courses of speciation of this genus then became highly attractive, but using morphological characters as the basis for classification was not helpful. Therefore, many authors struggled to solve the problem through karyotype analysis. Four allopatric/parapatric chromosomal races with $2 \mathrm{n}=52,54,58$, and 60 were discovered in Israel [53]. Data on chromosomes of almost all extant mole rats species have been collected [11] and extensive research was carried out in South-eastern Europe in subsequent years [29].

The number of species acknowledged in the lesser BMR is disparate and ranges from a single one $[1,56]$ to fourteen species in Europe [29]. Most authors recognize three Nannospalax species (=morphospecies/superspecies). Thus, N. leucodon (Nordmann, 1840), the Mediterranean BMR, inhabits South-eastern Europe; N. xanthodon (Nordmann, 1845) (synonym: N. nehringi (Satunin, 1898), the Anatolian BMR, inhabits Transcaucasia, most of Turkish Anatolia, and certain East Aegean islands; N. ehrenbergi (Nehring, 1898), the Israeli BMR, inhabits South-eastern Anatolia in Turkey, Iraq, Syria, Lebanon, Israel, Jordan, and Egypt. Several authors have joined N. xanthodon and N. leucodon into N. leucodon superspecies (e.g., [39,57]) or a separate genus Mesospalax [14]. Anatolia can be considered the core area of differentiation processes in chromosomal evolution within BMRs [31,39,58,59], as all three Nannospalax morphospecies were recorded in this region. N. leucodon is presumably restricted to the Turkish part of Thrace and its occurrence in the western parts of Anatolia is not certain $[40,60]$. However, distinguishing between N. xanthodon and N. ehrenbergi may be difficult even with the use of both morphological and chromosomal characters [61].

Each of these three Nannospalax species is most probably a monophyletic collection of closely related and morphologically similar but actively speciating populations at different stages of this process. They putatively evolved through CRs, alternatively entitled cytotypes, chromosomal forms/races, sibling species, good biological species, cryptic species, or evolutionary significant units (ESU's; Moritz, 1994) [1,4,5,12,14,31,36,40,50,53,62-65].

A chromosomal race was defined as a group of geographically contiguous or recently separated populations, which share the same chromosome complement by descent, using the common shrew Sorex araneus as an example [66]. The authors further proposed that geographically isolated populations with the same karyotype should be merged into the same race, only if there is proof that they have separated recently and share all their chromosomes by common ancestry. This view was adjusted to the BMRs [29]. Populations with similar karyotypes differing particularly in the number of chromosomal arms or even in $2 \mathrm{n}$ were exceptionally included in the same race $=\mathrm{CF}$, because 
variability observed within one CF may be an artefact of comparisons of findings published in different reports. For CFs with proved reproductive isolation, specific ecological preferences, and wide biogeographical distribution, we find it appropriate for now to use the term cryptic species or cryptospecies. This corresponds to two or more morphologically similar evolutionary lineages that were erroneously classified and hidden under one species name (see [67]).

\section{Mediterranean BMR N. leucodon Cryptospecies}

The taxonomy, speciation mechanisms, origin, and distribution patterns of Spalacinae from South-eastern Europe have been studied from different aspects. However, many questions, mostly concerning taxonomy and phylogenetic interrelationships between different CF (or cryptospecies), are still open. On the basis of the above mentioned, it was established that the territory of former Yugoslavia was settled by a total of eight different species of the genus Spalax (= Nannospalax) [68,69]. The research was later continued [5,68-70] and all available cytogenetic, morphometric, craniometric, paleontological, zoogeographic, and biogeographic data summarized [29]. Six different $2 \mathrm{n}$ forms were recorded: $38,48,52,54,56$, and 58 , with no evident intrapopulation karyotype polymorphism (Table S1). However, the morphology of the autosomes within $2 n=54$ and 56 forms, between different population groups, often varied greatly, causing altered NF and NFa values. At the same time, it was shown that certain karyotype forms inhabit wide distributional areas.

\subsection{Phylogenetic Dendrogram}

Considering common characters in karyotype structure within some karyotype forms (e.g., a very small pair of metacentrics; the first two to three pairs of the largest subacrocentrics; or the two smallest pairs of submetacentric autosomes), morpho- and craniometric differences, dissimilarities in habitat, natural barriers (large forest complexes, wide bodies of water, humid soil, rocky deserts, different altitudes), and evidence for reproductive isolation, a hypothetical dendrogram with phylogenetic relationships and the speciation courses between all documented karyotypically different forms was constructed $[29,71]$. It was hypothesized that during the process of allopatric speciation, a variety of karyotypes emerged as a result of adaptation to different environments. Therefore, from a common initial ancestor (which probably had $2 \mathrm{n} \sim 60$ and a high number of acrocentric chromosomes) four basic groups of CFs have diverged: the Yugoslav branch, the Central Balkan branch, the Serbicus branch, and the East Balkan branch (the numbers of CFs in the text correspond to Figure 1, Table 1, Tables S1 and S2).

I The Yugoslav Branch (NF = 82-90) is characterized by the presence of a very small pair of metacentric autosomes.

1. montanoserbicus (Savić and Soldatović, 1974) $2 \mathrm{n}=56$; $\mathrm{NF}=82$; with $15-16$ pairs of small acrocentrics is probably a relic of an ancestor originally settled in the Central Balkan region. Today its populations occupy a wide discontinuous area of island-type isolates of preglacial Mid-Balkan Mountains (the Rhodope Mt.-Dinaride in Hercegovina and Montenegro), over $700 \mathrm{~m}$ a.s.l. It is possible that the area of this CF spreads to the territory of the Rhodopes in neighboring Bulgaria as well. The forms hercegovinensis and syrmiensis probably originate from it [29]. They share an identical $2 \mathrm{n}$ and NF, but with significant dissimilarities in the morphology of some autosomal groups. There are no data regarding reproductive isolation between them. Nevertheless, considering the morpho and craniometric discrepancies, the geographical distance between their distributional areas and the biogeographic differences among their habitats, they could be considered as a biologically separate species-cryptospecies.

2. hercegovinensis (Mehely, 1909) $2 \mathrm{n}=54 ; \mathrm{NF}=90$ was described as a separate form (species) [68] recorded in the Dinaric Mountains in Montenegro and Hercegovina. 
3. syrmiensis (Mehely, 1909) $2 \mathrm{n}=54 ; \mathrm{NF}=90$ is a group of populations with different chromosomal morphology from hercegovinensis. They occupy the plains of Srem and the right bank of the rivers Sava and Danube from the entry of the river Drina into the Sava and the Great Morava into the Danube. A slight discrepancy in karyotype structure (see Table S1) has been recognized in one population (Banovo Brdo, Belgrade).

II The Central Balkan Branch is characterized by very similar NF values, divided into two subsidiaries: the North Balkan branch (hungaricus, transsylvanicus, leucodon, montanosyrmiensis, and monticola) and the South Balkan branch (hellenicus, thracius, strumiciensis, makedonicus, and epiroticus). This group diverged very early with $2 \mathrm{n}$ almost 60 for hellenicus, epiroticus, and leucodon, all characterized with fourteen pairs of acrocentric autosomes. The CF leucodon drifted to the northern part of the Balkan Peninsula and generated the northern branch-CFs hungaricus, transsylvanicus, montanosyrmiensis, and monticola with variable $2 \mathrm{n}=48-54$, but almost identical NF, namely 84 or 86 . The Makedonian branch diverged from the epirus CF, while the CFs strumiciensis and thracius separated from the initial branch somewhat later.

IIa North Balkan subsidiary branch. The existence of reproductive isolation between some CFs has been proved.

4. hungaricus (Nehring, 1898) $2 \mathrm{n}=48$; $\mathrm{NF}=84$ inhabits a large area of Pannonian lowland in Bačka, Banat, and a narrow belt in northern Serbia, where it overlaps with syrmiensis on the slopes of Mt. Avala.

5. transsylvanicus (Mehely, 1909) $2 \mathrm{n}=50 ; \mathrm{NF}=84$ is distributed in North-western Romania [62] and Eastern Hungary [33]. It was described as a possible subspecies of $N$. hungaricus [29] because of the highly similar karyotype.

6. montanosyrmiensis (Savić and Soldatović, 1974) $2 \mathrm{n}=54 ; \mathrm{NF}=86$ is a relict species present on Fruška Gora, where two populations with a difference in the Y chromosome exist, and additionally in Kelebia on the Serbian/Hungarian border [42].

7. leucodon (Nordmann, 1840) $2 \mathrm{n}=56$; $\mathrm{NF}=84$ is distributed in Moldavia, Dobrudzha, Odessa and South-western Ukraine [11]. There is a certain chromosomal similarity with dobrudzha CF, so a recent hypothetical dispersal of N. leucodon into Moldova and Southern Ukraine from the southwest was suggested. Nearby on the Black Sea coast, Eastern Bulgaria, varna $\mathrm{CF}(2 \mathrm{n}=52, \mathrm{NFa}=76, \mathrm{NF}=80)$ was reported but only from description of the locality [72].

8. monticola (Nehring, 1898) is a relict species $2 \mathrm{n}=54 ; \mathrm{NF}=84$ that occupies the western border of the Mediterranean BMR range, i.e., Kupreško Polje, Bosnia and Herzegovina. The area probably spreads to the central parts of the Dinaric massif. Although the karyotype is similar to that of montanosyrmiensis, morpho- and craniometrics diverge on a greater scale.

IIb South Balkan subsidiary branch $(2 \mathrm{n}=54,56$ and 58; NF $=84$ and 88). They inhabit the South-eastern and far Southern parts of the Balkan Peninsula. According to karyotype similarities and morpho- and craniometric characters, several forms could belong to this CF:

9. makedonicus (Savić and Soldatović, 1974) $2 \mathrm{n}=52 ; \mathrm{NF}=86$ inhabits the South-western Balkan Peninsula including Western Makedonia, North-western Greece, and probably spreading into neighboring Albania.

10. strumiciensis (Savić and Soldatović, 1974) $2 n=54 ; N F=88$ occurs in Dabilja, Strumica Valley, Macedonia (FYROM).

11. epiroticus (Savić, 1982) $2 \mathrm{n}=56 ; \mathrm{NF}=84$ is found in Lefkothea, Epirus, Greece.

12. thracius (Savić, 1982) $2 \mathrm{n}=56 ; \mathrm{NF}=88$ inhabits Novo Selo on the Thracian plain, Bulgaria.

13. hellenicus (Mehely, 1909) $2 n=58 ; N F=88$ was recorded in Parnas, Greece. 
According to their morphological characters several more CFs were described as thermacius (Hinton, 1920) (= strumiciensis), insularis (Thomas, 1917), thessalicus (Ondrias, 1966), and peloponnesiacus (Ondrias, 1966) [29].

III The Serbicus Branch has a very high NF of 90-98. The first CF to develop was the Sofia-East population with 11 pairs of acrocentric autosomes. CFs ovchepolensis and serbicus were formed later, as well as the tranensis $\mathrm{CF}$, represented by only one population and possibly rhodopiensis $\mathrm{CF}$, also represented by a single population in Dobrostan, Bulgaria, although this form digresses slightly from other CFs of this branch.

14. serbicus (Mehely) 2n $=54 ; \mathrm{NF}=98$ includes several CFs that are reproductively isolated from neighboring CFs. They inhabit valleys of Eastern Serbia, Northern Makedonia, Kosovo, and South-western Bulgaria. The suggestion that morpho- and craniometric characters are similar to monticola, hungaricus, and montanosyrmiensis, because of a common ancestor, should be further explored. Some authors recognize the highly similar CF lom in two isolated areas in North-western and South-western Bulgaria [72].

15. ovchepolensis (Savić and Soldatović, 1974) $2 n=54 ; N F=94$ is found at Ovče Polje, Makedonia (FYROM).

16. tranensis (Peshev, 1981) $2 \mathrm{n}=54 ; \mathrm{NF}=96$ was recorded in Tran, Bulgaria.

17. sofiensis (Peshev, 1983) $2 \mathrm{n}=56 ; \mathrm{NF}=90$ was registerd in Cherven Briag, Bulgaria.

18. rhodopiensis (Peshev, 1981) $2 n=54 ; \mathrm{NF}=92$ occurs in Dobrostan, Bulgaria and should be analyzed in greater detail regarding karyotype structure [72].

IV East Balkan Branch. Contrary to pronounced $2 \mathrm{n}$ differences, the NF values vary within narrow limits of 74 to 78 and therefore it was suggested that Robertsonian fusions of acrocentric autosomes were mostly responsible for the karyotype transformations. No crossbreeding experiments have been done in this group.

19. turcicus (Mehely, 1909) $2 \mathrm{n}=56$; $\mathrm{NF}=78$ has seventeen pairs of acrocentric autosomes and was the first to diverge from the basic branch. Now it probably represents the oldest existing form and inhabits the Lower Thrace lowlands.

Out of the same group, two CFs were formed in Bulgaria — srebarna and kozarevets, with nine and eight pairs of acrocentric autosomes, respectively.

20. bulgaricus (Peshev, 1981) $2 \mathrm{n}=46$ and $48 ; \mathrm{NF}=76$ consists of two populations with different karyotypes.

21. srebarnensis (Peshev, 1981) $2 \mathrm{n}=48 ; \mathrm{NF}=78$ is found in Russe, Targoviste, and Silistra regions in North-east Bulgaria.

Populations from the western part of Asia Minor, the island of Lesbos, and probably other islands in the Aegean Sea, as well as being designated as N. nehringi (Satunin, 1898) $2 n=38$; $\mathrm{NF}=74$. (N. n. anatolicus Mehely, 1909), were later shown to belong to the Anatolian BMR species N. xanthodon CF anatolicus [14,40].

\subsection{Natural Hybrids}

Some of these CFs live sympatrically, i.e., their areas touch or partially overlap. Investigations in the bordering zones of populations with different karyotypes revealed no cases with natural hybrid karyotypes [29]. The closest contact was noticed between hungaricus and syrmiensis on the slopes of Mt. Avala, where they live sympatrically in the same area (more precisely, in the same meadow) and between hungaricus and montanosyrmiensis in Kelebia-Subotička peščara [46]. Great differences in chromosome morphology could be the most probable reason for this reproductive isolation. The CF 
syrmiensis is also territorially linked to the montanosyrmiensis form, but their areas diverge vertically. Likewise, no animals with hybrid karyotypes have been registered either. Two different CFs were observed on other mountains. Thus, montanoserbicus occupies the higher altitudes of Mt. Kopaonik and the Balkan Mountain range, but in the lower areas and foothills the serbicus form was very densely settled. Even without any natural obstacles, not a single hybrid was found in the contact zones. Also, the parapatric CFs, makedonicus, serbicus, and ovchepolensis, with boundaries in central Makedonia, similarly showed no natural hybrids. Thus, the conclusion is that the separate CFs are probably different biological species (cryptospecies), reproductively isolated for a long time.

Remarkably, despite a variety of karyotypes in BMRs, hybrids between individual chromosomal forms have been found only sporadically over the entire distributional area. Hybrids are also apparently absent or very infrequent in Anatolia [39,57,73-75], with only three $2 n=49$ probable cases located in Central-eastern Anatolia [76]. Hybridization is commonly described only for Israel [53,77], with lower fitness compared to their parents [78].

\subsection{Experimental Crossbreeding}

Experimental crossbreeding results [29] greatly contributed to the conclusion that karyotype changes lead to reproductive isolation. When males and females belonging to the same CF were paired, they mated with resulting embryos. Moreover, when animals from the same CF but from geographically distant populations were paired, the result was always positive (Table 2). However, although pairing individuals with different CFs was followed by mating in most cases, no embryos were formed. Pre and post copulation reproductive isolation between different $\mathrm{CFs}$ demonstrated by experimental crossbreeding was confirmed by artificial insemination performed in similar combinations. Embryos developed only when the same CFs were combined. Chromosome preparations made from embryo fibroblast cultures showed no differences between their karyotypes and those of their parents. These experiments did not include all recorded N. leucodon CFs. Instead, importance was given to marginally sympatric forms, with touching or overlapping distributional areas, or sites separated by natural barriers/different altitudes.

Table 2. Experimental crossbreeding results, from [29].

\begin{tabular}{|c|c|c|c|}
\hline Female CF & Male CF & Mating & Embryos \\
\hline hungaricus * & hungaricus * & + & + \\
\hline hungaricus & syrmiensis & + & - \\
\hline hungaricus & montanoserbicus & - & - \\
\hline hungaricus & montanosyrmiensis & + & - \\
\hline syrmiensis & montanosyrmiensis & + & - \\
\hline syrmiensis & montanoserbicus & - & - \\
\hline makedonicus & montanoserbicus & + & - \\
\hline montanoserbicus & serbicus & + & - \\
\hline syrmiensis & serbicus & + & - \\
\hline monticola & hungaricus & + & - \\
\hline monticola & montanosyrmiensis & + & - \\
\hline montanosyrmiensis & syrmiensis & + & - \\
\hline syrmiensis & hungaricus & + & - \\
\hline montanoserbicus * & montanoserbicus * & + & + \\
\hline
\end{tabular}

* Combinations of the same CF from geographically distant populations. 


\section{Chromosomal Rearrangements in Nannospalax leucodon}

The extensive karyotype variation in Nannospalax arises from numerous and still insufficiently identified chromosomal changes, because studies using banding techniques or molecular cytogenetic methods have been rather rare [79-82]. Mechanisms of chromosomal evolution already recorded in this group are Robertsonian rearrangements (fusions and fissions), additions/deletions of C-heterochromatin, pericentric inversions, centromeric shifts, euchromatin deletions, positional changes of the nucleolar organizing regions (NOR) sites, missing whole chromosomes, or supernumerary B chromosomes $[29,53,60,79,83]$. Most confirmations about mechanisms of karyotype evolution have hitherto been obtained for Israeli BMR species and cytotypes.

In general, Robertsonian rearrangements are considered to be the major mechanism of $2 n$ chromosomes changes in Nannospalax. Processes of divergence were probably peripatric with Robertsonian changes fixed in small isolated marginal populations, though the direction of these alterations is a matter of long lasting debate. It is difficult to decide which of the following hypotheses is correct. The fusion hypothesis assumes that, during the karyotype evolution of N. leucodon, Robertsonian rearrangements most probably acted in the direction of a decrease in the number of acrocentric autosomes and $2 \mathrm{n}[29,60]$. Similarly, some authors considered chromosomal fusion as the major force of karyotype evolution in BMRs $[81,84,85]$. The fission hypothesis suggests a reverse tendency for increasing $2 n$ through Robertsonian fissions in both Turkey and Israel, by fission of metacentrics to form acrocentric chromosomes, as the major initial mechanism of chromosomal evolution in BMRs $[58,83]$. During this process the number of acrocentrics increases, while changes in the NF derive from centromeric shifts. The ancestral Spalacine karyotype was $2 n=38$, increasing progressively in different lineages [58,83].

According to analysis of ten Anatolian CFs, $2 n=60 \mathrm{C}$ is the ancestral CF and $2 n=38$ and $2 n=60 \mathrm{~K}$ are secondary ancestral CFs [81]. Therefore, Robertsonian fusions have the main role in chromosomal evolution of BMRs in Turkey, while Robertsonian fissions and pericentric inversions/deletion are minor forces in their chromosomal evolution $[79,81]$. Which factor causes these rearrangements is still not conclusively known and there is a clear necessity for detailed chromosomal studies using both differential staining techniques and molecular cytogenetic methods that, up till now, have been very limited.

G-banded chromosomes of $N$. (= Spalax) leucodon have been described only from two distant populations. Namely, Mt. Bistra, North-western Makedonia $(2 n=52, N F=86)$ [86], and N. xanthodon (labelled as leucodon) from Malatya, Turkey $(2 n=60, N F=78)$ [79]. C-banding distribution of NORs was accomplished only for the Malatya population [79].

Notwithstanding the enormous chromosomal differentiation observed among $N$. leucodon species, only a few could be used to distinguish between them. Distinctive markers, i.e., the chromosomal changes observed between the recognized taxa, included two or three noticeably large subtelocentric autosomal pairs characterizing the karyotype of most populations of the Mediterranean BMR, N. leucodon, from South-eastern Europe with certain exceptions (varna, bulgaricus, and srebarnensis CF) [29].

\section{The Fusion or Fission Hypothesis?}

It is difficult to define any universal chromosomal changes that could explain the course of speciation of currently recognized taxa of BMRs. As stated above, Robertsonian rearrangements, fixed in small isolated marginal populations, are considered to be the major mechanism of $2 \mathrm{n}$ chromosomes changes in Nannospalax. However, the direction of these changes is a matter of a long lasting debate.

Chromosomal speciation and adaptive radiation of BMRs in Asia Minor and the Middle East were correlated with increased ecological stress $[38,57,58]$. This association was established, firstly due to the possibility that fissions of metacentric chromosomes largely increase haplotype diversity. This may further elevate population adaptation to climatic stress. Secondly, there is the notion that species and races with the highest $2 \mathrm{n}$ from the entire Spalacinae distributional area occupy the most xeric regions and those with the lowest $2 \mathrm{n}$ live in mesic habitats in the center of their range. A number 
of studies (Section 4) have indicated that the speciation course of the Israeli BMR N. ehrenbergi from lower to higher $2 \mathrm{n}$ as it moves southwards to a more arid and warmer habitat is highly credible. However, generalization of these events to other lineages of BMRs, widely distributed in Anatolia and South-eastern Europe, is not sound. The majority of N. leucodon CFs have not been thoroughly studied, especially by molecular methods. Furthermore, the complex biogeographical history of the Balkan Peninsula [87], as well as new paleontological data [44,47,48], do not allow such universalization of speciation events. More detailed genetic research including extant and extinct samples, combined with molecular cytogenetic methods, are necessary to explain karyotype evolution in this group.

Elevation to species level of three N. xanthodon CFs was recommended based on genetic separation [88]. Although the studied sample included ten individuals with $2 n=60$, one with $2 n=58$, and two with $2 n=40$, the authors argue that the basal position of the CF with the lowest $2 n$ of 40 in the inferred phylogenetic tree (rooted with N. ehrenbergi from Diyarbakir locality, $2 n=52$ or 56 ) strongly supports the fission hypothesis. However, other molecular phylogenetic studies showed that the populations with lower $2 \mathrm{n}$ did not hold basal positions, but rather appeared in the internal branches $[14,50,65,89]$. Several additional investigations indicated chromosomal fusion as the major force for karyotype evolution in BMRs $[81,84,85]$. A phylogenetic dendrogram based on G- and C-banding techniques showed that populations with $2 n=60$ were the ancestors of all CFs [81]. The opposite direction of Robertsonian rearrangements and a decrease in the number of acrocentric autosomes, together with $2 \mathrm{n}[29,60]$, has acquired several more confirmations. Namely, monophyly of two major lineages of extant BMRs, the genera Spalax $(2 n=60-62)$ and Nannospalax $(2 n=38-60)$, was confirmed by comprehensive research $[10,15,50,52]$, so the most probable scenario is that their common ancestor had a karyotype with a high $2 \mathrm{n}(60)$ involving mostly acrocentric autosomes. It was observed that the ancestral form of chromosomally diversified species is most probably the one with the largest distribution [7]. Thus, populations with the highest $2 \mathrm{n}$ of 60 from both Spalax and Nannospalax genera are widely distributed. For example, the $N$. xanthodon cytotype $2 n=60$ inhabits almost all climatic zones in Anatolia [73,90].

As for recent representatives, on the basis of phylogenetic dendrogram studies of fossil Spalacinae, it was established that several parallel courses of speciation exist at the same time, as well as certain side branches with blind endings [29]. Finally, it seems that the direction of Nannospalax karyotype evolution is more complicated and variable. The evolution courses of the three morphospecies (= species groups) N. leucodon, N. xanthodon, and N. ehrenbergi, could be completely divergent, i.e., the fusion hypothesis may be valid for N. leucodon and some N. xanthodon representatives and the fission hypothesis for N. ehrenbergi.

\section{Molecular Research in the Subfamily Spalacinae}

In general, the majority of molecular studies have explored the Israeli N. ehrenbergi species complex $[14,50,57,58,65,91]$, while Mediterranean BMRs ( $N$. leucodon CFs) have received only sporadic attention. Thus, the overall phylogenetic pattern in all extant BMRs is far from resolved.

Recent speciation events and slight genetic changes were reported in an isozyme study on seven Spalacinae species from both genera [51]. The results were in agreement with the karyological classification: I N. nehringi (TfA, $\mathrm{HbB}$ ); II N. leucodon (TfB, HbC); III S. microphthalmus (TfC, $\mathrm{HbA}$ ); IV S. graecus (TfB, $\mathrm{HbA} / \mathrm{HbB}) ;$ S. polonicus $(\mathrm{TfB}, \mathrm{HbB}) ;$ S. arenarius $(\mathrm{TfB}, \mathrm{HbB}) ;$ and S. giganteus (TfB, $\mathrm{HbB})[10]$.

The Major Histocompatibility Complex (MHC), highly polymorphic in both classes of polypeptides in N. ehrenbergi, showed low polymorphism in four Balkan CFs: N. syrmiensis, $N$. montanosyrmiensis, N. hungaricus, and N. makedonicus [92]. The estimation that $N$. leucodon CFs might have very low genetic diversity should be considered with caution due to limited sampling (three out of the four examined species inhabit steppe habitats of the Sub Pannonian hilly and mountain foot areas, some of them even sympatrically), difficulties were reported with mouse probe hybridizations with Spalax DNA, etc. 
Allozyme diversity studies support the environmental selection hypothesis of genetic diversity among N. ehrenbergi CFs from Turkey, Israel, and Egypt [58]. Genetic distances (D) ranged from 0.001 to 0.269 , with the highest value between ancestor Turkish and descendant Israeli and Egyptian species. It was estimated that climatic selection in Turkey appeared to be the major diversity factor in both speciation and adaptation. Accordingly, mtDNA diversity in N. ehrenbergi was found to be significantly correlated with the climate, pathogens, and different molecular and physiological factors [93]. Gene flow and introgression seemed to play a minor role, while natural selection at the macro- and microgeographic levels appeared to be the major differentiating factor. mtDNA diversity in the youngest species $(2 n=60)$ was higher than in the oldest species pair $(2 n=52$ and 54$)$.

In agreement with the above-mentioned findings, a study of $1140 \mathrm{bp}$ cyt $b$ sequences in 53 individuals of all three morphospecies of the lesser mole rat [14] pointed to division of the genus Nannospalax into two subgenera Nannospalax s.s. (N. ehrenbergi) and Mesospalax (N. xanthodon and N. leucodon) [12]. However, sixteen individuals of N. leucodon from this sample, namely N. hungaricus, N. serbicus, N. makedonicus, and N. hercegovinensis, were designated indirectly without karyotyping, by presuming their $2 \mathrm{n} / \mathrm{NF}$ from localities recorded $40-50$ years earlier [29]. There was a mean distance of $5 \mathrm{~km}$ between the new and previously documented localities. On the contrary, the karyotypes and DNA sequences of N. xanthodon and N. ehrenbergi specimens were analyzed completely and confirmed. The authors found that among the three morphospecies, genetic diversity was lowest in N. leucodon $(2.4 \% \pm 0.3 \%)$, highest in N. xanthodon $(8.8 \% \pm 0.7 \%)$, and intermediate in $N$. ehrenbergi $(5.0 \% \pm 0.5 \%)$. However, while N. leucodon comprises 25 CFs, N. xanthodon 29 CFs, and N. ehrenbergi 20 CFs $[31,61]$, only four CFs of $N$. leucodon were included $(2 n=48,52$, and 54$)$ and, as expected, the lowest genetic diversity was recorded among them. The highest diversity was in N. xanthodon (the sample $2 \mathrm{n}$ ranged from 38 to 60 ), while genetic diversity among $N$. ehrenbergi $(2 n=52,54,58$, and 60$)$ was intermediate. Therefore, conclusions regarding the origin and further evolutionary scenario deduced from these results should be taken with reserve, especially in the light of the newest data [47,48].

The most comprehensive phylogenetic analysis of five mtDNA sequences (12S ribosomal RNA (rRNA), transfer RNA (tRNA)-Val, 16S rRNA, tRNA-Leu (UUR), NADH dehydrogenase subunit 1 (NADH1), tRNA-Ile, 3742 bp in total) in 41 samples from 35 different populations of BMRs [50] indicated the highest rates of heterogeneity according to the Maximum likelihood phylogram between Spalax/Nannospalax 0.1577. Inside the genus Spalax, heterogeneity rate was 0.039; between the two superspecies, $N$. leucodon and $N$. xanthodon, 0.0623 , but much higher $(0.1066)$ between these two superspecies on one side and N. ehrenbergi at the other. For N. leucodon superspecies, comparable values were: 0.0447 for montanosyrmiensis to srebarnensis; 0.0255 srebarnensis to hungaricus; and 0.0113 hungaricus to transsylvanicus. In N. ehrenbergi superspecies, the values between species were slightly higher: 0.0397 for galili to golani; and 0.0361 juadei to carmeli. Inside N. xanthodon superspecies the range was from 0.0172 to 0.056 .

Comparison of $1140 \mathrm{bp}$ mtDNA sequences of four individuals of S. graecus with 43 sequences from N. leucodon, xanthodon and ehrenbergi samples from GenBank [15], provided noticeably higher pairwise Kimura two-parameter genetic divergences among the genera Spalax and Nannospalax, than between three Nannospalax species. These results confirmed the taxonomic distinctiveness of the two genera.

As the evolution of a particular gene is not necessarily identical with the evolution of the species [94], above results of mtDNA cyt $b$ gene analysis could serve only as an initial step in untangling the complex evolutionary history of the BMRs.

Microsatellite (MS) markers analysis of the twelve populations of S. ehrenbergi superspecies [95] revealed positive correlation between MS diversity and aridity stress. Natural selection appears adaptively to determine MS evolution in Spalax regionally across the distributional area. Very low gene flow was reported between species pairs, except for one population of $N$. carmeli $(2 n=58)$ located near the hybrid zone between it and S. golani $(2 n=54)$. This analysis confirmed the earlier described pattern $[58,89,96]$ of northern (older) and southern (younger) species pairs, which represent different stages of evolutionary divergence. 


\section{Cryptic Speciation in N. leucodon}

It is well known that chromosomal number and morphology are general characteristics of the species of one genus, or even genera from the same family. Thus, karyotype polymorphism between them is not a common phenomenon. The highest rates of karyotype variability are found in muroid rodents, canids, gibbons, and equids. Nevertheless, in each of them there are taxa with completely opposite rates of chromosomal change: e.g., the Sciuridae family among rodents, apes among primates, and rhinoceroses among perissodactyls [8]. Environmental effects, total mutation rates, population size, mobile elements, and retroviruses could contribute to this distinction [8]. The "Court Jester" evolution model, which promotes the effects of Quaternary climatic change on speciation in mammals, was recently proposed for Spalacinae species [50]. Paleobiological studies indicate that large-time scale patterns of biodiversity are driven by the physical environment, including geological and tectonic events, landscape, food supply, or climate. Besides strong support for the majority of branching events on the tree, the absence of support in a few instances indicates that network-like evolution could exist in BMRs [50].

Similarly to Nannospalax, there are other well-documented examples of mammalian species complexes with clear chromosomal separation of the species, i.e., groups of chromosomal forms (e.g., Rhogeessa tumida, Ellobius tancrei, and Nannomys minutoides) [97]. The most diversified are the 72 known chromosomal "races" of the common shrew, Sorex araneus [98] and 97 chromosomal "populations" in the house mouse, Mus musculus [99]. Chromosomal forms in these two species were formed recently and most studies showed no signal of molecular diversification [98,99]. In comparison, Microtus arvalis $(2 \mathrm{n}=46)$ has two chromosomal races (Western European arvalis and Eastern Asian obscurus) that are considered subspecies because they are not reproductively isolated, despite the chromosomal and genetic differentiation (demonstrated by Fluorescence In Situ Hybridization (FISH) analysis). Therefore, they are classified into the superspecies complex Microtus arvalis s.l.

There are multiple instances that provide support for the hypothesis that some of the 74 described Nannospalax CFs [31,61] represent valid cryptic species. Besides three morphospecies, N. leucodon, N. xanthodon, and N. ehrenbergi, the only CFs acknowledged in the literature as separate species are four Israeli BMRs, Spalax (= Nannospalax) galili, S. golani, S. carmeli, and S. judaei $[36,96,100]$. These species represent young, closely related allospecies in the early stages of speciation, i.e., as the evolutionary youngest, occupying different climatic regimes. Nevertheless, phylogenetic analysis did not confirm separation of the last two species, S. carmeli and S. judaei $[65,96,100]$, similarly to earlier findings [89]. Moreover, hybrids were frequently reported only in Israel [53,77], with lower fitness compared to their parents [78].

Recently it was suggested that four BMR species inhabit Anatolia-N. ehrenbergi in the southeast, N. nehringi in the east, N. xanthodon in the west, and N. labaumei in central Anatolia [101]. Moreover, four CFs of $N$. xanthodon $2 n=36,38,40,52$, should be treated as valid biological species $[75,102]$.

Here we recommend cryptospecies rank for seven reproductively isolated $N$. leucodon CFs (Table 2, Table S2) with sympatric and parapatric distribution: Nannospalax montanoserbicus (Savić and Soldatović, 1974), Nannospalax syrmiensis (Méhely, 1909), Nannospalax makedonicus (Savić and Soldatović, 1974), Nannospalax hungaricus (Nehring, 1898), Nannospalax montanosyrmiensis (Savić and Soldatović, 1974), Nannospalax monticola (Nehring, 1898), and Nannospalax serbicus (Méhely, 1909), according to the following criteria: reproductive isolation (absence of hybrids), sympatric/parapatric distribution with ecogeographic differences, morphological modifications, and genetic distance.

\subsection{Reproductive Isolation}

In the early stages of speciation, phenotypic, karyotypic, and genotypic evolution rates may progress independently [7]. The fact that karyotype differences influence speciation throughout the appearance of reproductive isolation was recorded long ago in two types of morphologically similar fruit flies, previously treated as one species [103]. For such cases, the term sibling, i.e., sister species was introduced, describing the presence of reproductive isolation as the basic criterion for 
raising a natural population, or group of populations, to the species rank [104]. More than 40 new cryptic species were recorded in the Palaearctic and 24 in Europe [7]. Some CRs can cause fertility problems or sterility in hybrids, acting as genetic barriers to gene flow between populations with fixed chromosomal differences $[105,106]$. In two parapatric populations connected by symmetric gene flow, chromosome changes can delay the fixation of favorable alleles and allow incompatibilities to accumulate [107]. Populations will become increasingly differentiated until speciation is complete. Genic and nongenic mechanisms can act together in speciation, as proposed a long time ago [108]. It was also observed that groups with higher rates of chromosomal changes have greater speciation rates [109]. The significant role of CRs in the process of speciation was later confirmed in other organisms $[3,29,36,110]$.

In the case of mole-rats, reproductive isolation, together with the adaptation of diverse chromosomal forms to different ecological conditions $[57,83,111]$, leads to complete detention in the gene flow. During chromosomal speciation, changes like Robertsonian fusions occur in peripheral populations [106] proceeding slowly to reproductive isolation from the main population. Since genetic discrepancy still remains low, a small hybrid zone may be retained between them. However, genetic and morphological differences accumulate and recently separated populations disperse into new areas or habitats [106]. Poor movability, solitary, and territorial and aggressive behavior have certainly contributed to spatial isolation and the appearance of divergent speciation of karyotype forms leading gradually to their complete reproductive isolation $[60,68]$.

The experimental hybridization method has been successfully applied to refine unclear taxonomic affiliation of various forms [112,113]. It provides important information about the degree of divergence of closely related species and allows the mechanisms of reproductive isolation to be studied. Such experiments, together with artificial insemination and the absence of hybrid individuals in their natural habitats, have proved complete reproductive isolation and elucidated post- and/or pre copulatory isolation mechanisms. As mentioned above, natural hybrids are apparently absent or very infrequent in Anatolia $[39,65,73,74]$ but are commonly described only in Israel with lower fitness than their parents $[53,77]$.

\subsection{Sympatric/Parapatric Distribution}

Numerous described cryptic species have sympatric distribution, providing an important indirect confirmation of complete reproductive isolation of these distinctly derived groups [114]. Genetic differentiation of allopatric populations, however, might have contributed to local adaptation or genetic drift. An indicative feature of chromosomal changes in the genus Nannospalax is the parapatric or allopatric pattern of distribution of populations with a specifically changed karyotype. There are a few exceptions in N. leucodon, as some sympatrically distributed cryptospecies exist [29].

Models of chromosomal speciation do not postulate that all speciation events are due to CRs. Populations are likely to diverge genetically in allopatry and, under certain conditions, they also have the opportunity to accumulate CRs $[110,115]$. In order to explore if cryptic species are more frequent in allopatric or sympatric habitats, chromosomal speciation in 41 pairs of sister species was tested in the two most species-rich rodent families, Cricetidae and Muridae, to reveal a direct role of CRs in speciation [3]. About 30\% of sister species had an identical karyotype, and they were not randomly distributed but were more common for allopatric sister species than for sympatric ones. This study indicated that, after secondary contact, it is more likely that karyotypically diverged species will remain distinct than genetically diverged ones. This is because hetero-karyotypes are expected to be less fit than homo-karyotypes [110].

The results obtained for phylogenetic relationships of the karyotypic forms and possible evolution paths were confirmed by data concerning their biogeographic distribution [60]. Besides its geographical position between Europe, Asia, and Africa, the Balkan Peninsula is considered to have the most complicated relief due to diverse geomorphology and frequent changes in global ecological conditions [116]. 


\subsection{Morphological/Physiological Modifications}

Despite the extensive chromosomal variability, morphological and physiological modifications are not easily noticeable in BMRs, although some do exist [29,71]. It is also a common assumption that speciation of the most cryptic species is a recent event, so morphological characters or other diagnosable features have not had time to evolve. This may be true for some taxa, such as coccolithophores, but studies of bonefish amphipods and copepods show ancient divergences among cryptic species [114]. Even though chromosomal changes may induce morphological and physiological modifications, a disparate number of chromosomes (2n) does not necessarily alter the phenotype. Two morphologically very similar deer species, Indian and Chinese muntjacs, with $2 \mathrm{n}=6$ and 46, respectively, provide an extreme example [117].

A number of studies have explored the morphological characters of $N$. leucodon CFs. $([21,71,118]$ and others). The results of craniometric analysis were correlated with $12 \mathrm{CFs}$ from twenty different populations and directions of their migrations and speciation in the Balkan Peninsula BMRs were discussed [71]. Generally, specific phenotypic characteristics should be explored in Balkan CFs in greater detail. For example, there are some animals (insects, frogs, and fish) that communicate non-visually through sound, vibration, pheromones, or electrical signals, possibly hiding cryptic species, because changes in these types of signals may lead to reproductive isolation that is not morphological [114]. Therefore, studies of non-visual communication might contribute to explanations of reproductive isolation in BMRs.

\subsection{Genetic Distances}

To infer the amount of genetic change developing together with chromosomal rearrangements and phylogenetic estimates in such comparative studies, representative sampling is crucial. Therefore, the majority of $\mathrm{CFs}$ of each morphospecies should be equally included. Although the species rank of $N$. leucodon $\mathrm{CFs}$ was questioned, giving low cyt $b$ genetic divergences $[14,50]$, these studies were based on comparison of only four CFs, which is a small proportion of the 25 CFs described in total [31]. Furthermore, pairwise comparisons of genetic distances within the Mediterranean BMRs were of a similar scale as those among Israeli BMRs [14,50] and some Spalax species [50], which are already acknowledged as separate species. For example, genetic diversity within the serbicus/makedonicus lineage was $1.6 \% \pm 0.2 \%$; within the two major monophyletic lineages of the $N$. ehrenbergi morphospecies from Israel: galili/golani $(1.4 \% \pm 0.2 \%)$ and carmeli/judaei $(1.4 \% \pm 0.3 \%)$.

According to an older hypothesis, subterranean and fossorial mammals are generally characterized by significantly lower genetic diversity than other above-ground mammal species [119]. DNA-DNA hybridization studies indicated the relative number of interspecific nucleotide substitutions between four species of $N$. ehrenbergi to be $0 \%$ to $5 \%$, which suggests that adaptive chromosomal speciation does not have to be accompanied by major genomic changes [91]. Instead, it may happen with minor genomic changes in these animals.

There are almost $20 \mathrm{CFs}$ of the Mediterranean BMRs N. leucodon reported that should be involved in future molecular genetic research, including other genes beside cyt $b$, to obtain more realistic phylogeographical patterns. New sampling and comparison with older karyological data is required to confirm their presence and distribution.

\subsection{Further Perspectives}

Chromosome fissions and fusions, common mechanisms in karyotype evolution, represent illegitimate events that occur during meiosis, which are associated with changes in chromosome number [120]. Many of the breakpoint sites are connected to the formation of acrocentric chromosomes in some species and metacentric in others, e.g., between the domestic dog and the red fox [8].

Other types of more complex change detected by modern methods of molecular cytogenetics can be used in evolutionary studies. Structural differences (accidental crossing over between homologous 
segments on non-homologous chromosomes) may result in interchromosomal rearrangements and may be initiated by a chromosomal inversion within one of the segments. The breakpoint sites are usually located near telomeres and centromeres [8]. These structural changes do not necessarily produce phenotypic effects (e.g., geographically separate populations of Mus musculus), but they may induce reproductive isolation [121]. The reasons for differences in the rates of these illegitimate recombinations in different species during their evolution are still unknown.

Comparison of different directions in karyotype evolution of the conservative Spalax and the highly variable Nannospalax could provide answers to these questions. Exploring these discrepancies might reveal a possible connection to more fragile chromosomal regions like conserved or rare fragile sites. Lately, an effort has been made to explain the mechanisms of chromosomal instability at evolutionarily conserved fragile sites and their correlation with cancer [121]. It was discovered that the chromosomal breakpoints occurring in constitutionally balanced CRs in the human karyotype have a non-random distribution. Interestingly, highly significant associations of rare fragile sites were found with both evolutionary breakpoints and tandem repeats, with important implications for their role in chromosomal instability and therefore genome evolution [122]. The authors provided clear evidence for the existence of fragile chromosomal regions that are prone to reorganization and have been conserved in different lineages during evolution.

Molecular cytogenetic techniques, like FISH painting using whole chromosome probes, extend cytogenetic investigations of karyotype evolution, revealing a wide range of interchromosomal translocations. Cross-species chromosome painting has been used for comparative cytogenetic studies in rodents, identifying conserved blocks of chromosome homology between species and discovering combinations that reveal their evolutionary relationships [123]. However, Mus musculus chromosomes are highly rearranged and hence problematic to some extent for use in comparative studies in preference to those derived from species with conserved genomes (e.g., [124,125]). Accordingly, flow-sorted painting probes, isolated from the naked mole-rats, Heterocephalus glaber $(2 n=60)$, revealed probable fixations of CRs favored by environmental factors and/or their specific social structure [126]. The relatively limited resolution of whole chromosome probes does not allow detection of smaller rearrangements and intra-chromosomal changes, like inversions. Therefore, improved FISH-banding approaches, such as multicolor banding (MCB) [127-129], would be the method of choice for further research on chromosome evolution in BMRs and are essential for correct interpretation of genomic sequencing data in future studies. Consequently, it is necessary to develop specific BMR chromosome probes to characterize chromosomal breakpoints, map the observed CRs and measure their functional, genomic consequences in both non-variable Spalax and highly variable Nannospalax.

We suggested unofficial taxonomic rank cryptospecies for seven $N$. leucodon $C F$ s, which exist as separate biological species. The actual species status is yet to be proved with further studies. About twenty described CFs of the Mediterranean BMRs should be involved in future molecular genetic research, including other genes besides cyt $b$, to obtain more accurate phylogeographical patterns. New sampling and comparison with older karyological data are required to confirm their presence and distribution. Also, to identify and describe species-level diversity, it is crucial to use an integrative taxonomy based on evolutionary history, morphology, behavior and genetics. Comparing samples from extinct species with extant ones will allow reconstruction of the mechanisms of evolutionary and ecological processes that lead to divergence and reproductive isolation in the absence of morphological differentiation.

Supplementary Materials: The following are available online at www.mdpi.com/2073-4425/8/11/292/s1. Table S1: Karyotype structure of N. leucodon chromosomal forms (CF) from South-eastern Europe. M-metacentric, $\mathrm{SM}$-submetacentric, A-acrocentric, SA—subacrocentric; Table S2: Biogeographic distribution of N. leucodon chromosomal forms (CF) from South-eastern Europe.

Acknowledgments: This work was supported by the Ministry of Education, Science and Technological Development of the Republic of Serbia, Grant No. TR 311009. 
Conflicts of Interest: The authors declare no conflict of interest. The founding sponsors had no role in the design of the study; in the collection, analyses, or interpretation of data; in the writing of the manuscript, or in the decision to publish the results.

\section{References}

1. Musser, G.G.; Carleton, M.D. Order Rodentia. In Mammal Species of the World: A Taxonomic and Geographic Reference; Wilson, D.E., Reeder, D.M., Eds.; Johns Hopkins University Press: Baltimore, MD, USA, 2005; pp. 745-1601.

2. Baker, R.J.; Bradley, R.D. Speciation in Mammals and the genetic species concept. J. Mammal. 2006, 87, 643-662. [CrossRef] [PubMed]

3. Castiglia, R. Sympatric sister species in rodents are more chromosomally differentiated than allopatric ones: Implications for the role of chromosomal rearrangements in speciation. Mammal Rev. 2013. [CrossRef]

4. Soldatović, B.; Živković, B.; Savić, I.; Milošević, M. Comparative karyotype analysis of two populations of Spalax leucodon Nordmann, 1840. Arch. Biol. Nauka 1966, 18, 15-16.

5. Savić, I.; Soldatović, B. Die Verbreitung der Karyotypen der Blindmaus Spalax (Mesospalax) in Jugoslawien. Arch. Biol. Nauka 1974, 26, 115-122.

6. Zima, J. Comparative cytogenetics of Palaearctic mammals. Folia Zool. 1993, 42, 97-104.

7. Zima, J. Chromosomal evolution in small mammals (Insectivora, Chiroptera, Rodentia). Hystrix 2000, 11, 5-15.

8. Ferguson-Smith, M.A.; Trifonov, V. Mammalian karyotype evolution. Nat. Rev. Genet. 2007, 8, 950-962. [CrossRef] [PubMed]

9. Romanenko, S.A.; Perelman, P.L.; Trifonov, V.A.; Graphodatsky, A.S. Chromosomal evolution in Rodentia. Heredity 2012, 108, 4-16. [CrossRef] [PubMed]

10. Topachevski, V.A. The fauna of the USSR: Mammals, mole rats, Spalacidae. Nauka Leningr. 1969, 3, 1-308. (In Russian)

11. Lyapunova, E.A.; Vorontsov, N.N.; Martynova, L. Cytological differentiation of burrowing mammals in the Palaearctic. In Symposium Theriologicum II; Kratochvíl, J., Obrtel, R., Eds.; Academia: Prague, Czech Republic, 1974; pp. 203-215.

12. Gromov, I.M.; Baranova, G.I. Catalogue of Mammals in USSR. Nauka Leningr. 1981, 1-455.

13. Savić, I.R. Familie Spalacidae Gray, 1821-Blindmäuse. In Handbuch der Säugetiere Europas 2/I; Niethammer, J., Krapp, F., Eds.; Akademische Verlagsgesellschaft: Wiesbaden, Germany, 1982; pp. 539-584.

14. Kryštufek, B.; Ivanitskaya, E.; Arslan, A.; Arslan, E.; Bužan, E.V. Evolutionary history of mole rats (genus Nannospalax) inferred from mitochondrial cytochrome $b$ sequences. Biol. J. Linn. Soc. 2012, 105, 446-455. [CrossRef]

15. Chişamera, G.; Bužan, E.V.; Sahlean, T.; Murairu, D.; Zupan, S.; Kryštufek, B. Bukovina blind mole rat Spalax graecus revisited: Phylogenetics, morphology, taxonomy, habitat associations and conservation. Mammal Rev. 2014, 44, 19-29. [CrossRef]

16. Avivi, A.; Ashur-Fabian, O.; Amariglio, N.; Nevo, E.; Rechavi, G. p53-A Key Player in Tumoral and Evolutionary Adaptation, A Lesson from the Israeli Blind Subterranean Mole Rat. Cell Cycle 2005, 4, 368-372. [CrossRef] [PubMed]

17. Gorbunova, V.; Hine, C.; Tian, X.; Ablaeva, J.; Gudkov, A.V.; Nevo, E.; Seluanov, A. Cancer resistance in the blind mole rat is mediated by concerted necrotic cell death mechanism. Proc. Natl. Acad. Sci. USA 2012, 109, 19392-19396. [CrossRef] [PubMed]

18. Azpurua, J.; Seluanov, A. Long-lived cancer resistant rodents as new model species for cancer research. Front. Genet. 2013. [CrossRef] [PubMed]

19. Manov, I.; Hirsh, M.; Iancu, T.C.; Malik, A.; Sotnichenko, N.; Band, M.; Avivi, A.; Shams, I. Pronounced cancer resistance in a subterranean rodent, the blind mole-rat, Spalax: In vivo and in vitro evidence. BMC Biol. $2013,11$. [CrossRef] [PubMed]

20. Fang, X.D.; Nevo, E.; Han, L.J.; Levanon, E.Y.; Zhao, J.; Avivi, A.; Larkin, D.; Jiang, X.; Feranchuk, S.; Zhu, Y.; et al. Genome-wide adaptive complexes to underground stresses in blind mole rats. Nat. Commun. 2014, 5. [CrossRef] [PubMed] 
21. Nevo, E. Mosaic Evolution of Subterranean Mammals: Regression, Progression and Global Convergence; Oxford University Press: Oxford, UK, 1999.

22. Avivi, A.; Gerlach, F.; Joel, A.; Reuss, S.; Burmester, T.; Nevo, E.; Hankeln, T. Neuroglobin, cytoglobin, and myoglobin contribute to hypoxia adaptation of the subterranean mole rat Spalax. Proc. Natl. Acad. Sci. USA 2010, 107, 21570-21575. [CrossRef] [PubMed]

23. Malik, A.; Korol, A.; Hübner, S.; Hernandez, A.G.; Thimmapuram, J.; Ali, S.; Glasser, F.; Paz, A.; Avivi, A.; Band, M. Transcriptome Sequencing of the Blind Subterranean Mole Rat, Spalax galili: Utility and Potential for the Discovery of Novel Evolutionary Patterns. PLoS ONE 2011, 6, e21227. [CrossRef] [PubMed]

24. Schmidt, H.; Hangmann, J.; Shams, I.; Avivi, A.; Hankeln, T. Molecular evolution of antioxidant and hypoxia response in long-lived, cancer-resistant blind mole rats: The Nrf2-Keap1 pathway. Gene 2015. [CrossRef] [PubMed]

25. Nasser, N.J.; Avivi, A.; Shafat, I.; Edovitsky, E.; Zcharia, E.; Ilan, N.; Vlodavsky, I.; Nevo, E. Alternatively spliced Spalax heparanase inhibits extracellular matrix degradation, tumor growth, and metastasis. Proc. Natl. Acad. Sci. USA 2009, 106, 2253-2258. [CrossRef] [PubMed]

26. Ashur-Fabian, O.; Avivi, A.; Trakhtenbrot, L.; Adamsky, K.; Cohen, M.; Kajakaro, G.; Joel, A.; Amariglio, N.; Nevo, E.; Rechavi, G. Evolution of p53 in hypoxia-stressed Spalax mimics human tumor mutation. Proc. Natl. Acad. Sci. USA 2004, 101, 12236-12241. [CrossRef] [PubMed]

27. Shams, I.; Malik, A.; Manov, I.; Joel, A.; Band, M.; Avivi, A. Transcription Pattern of p53-targeted DNA Repair Genes in the Hypoxia-Tolerant Subterranean Mole Rat Spalax. J. Mol. Biol. 2013, 425, 1111-1118. [CrossRef] [PubMed]

28. Avivi, A.; Oster, H.; Joel, A.; Beiles, A.; Albrecht, U.; Nevo, E. Circadian genes in a blind subterranean mammal. III. Molecular cloning and circadian regulation of cryptochrome genes in the blind subterranean mole rat, Spalax ehrenbergi superspecies. J. Biol. Rhythm. 2004, 19, 22-34. [CrossRef] [PubMed]

29. Savić, I.; Soldatović, B. Karyotype evolution and taxonomy of the genus Nannospalax Palmer, 1903, Mammalia, in Europe. Serbian Acad. Sci. Arts Sep. Ed. 1984, 59, 1-104.

30. Nevo, E. Stress, adaptation, and speciation in the evolution of the blind mole rat, Spalax, in Israel. Mol. Phylogenet. Evol. 2013, 66, 515-525. [CrossRef] [PubMed]

31. Arslan, A.; Kryštufek, B.; Matur, F.; Zima, J. Review of chromosome races in blind mole rats (Spalax and Nannospalax). Folia Zool. 2016, 65, 249-301.

32. Kryštufek, B.; Amori, G. Nannospalax leucodon. The IUCN Red List of Threatened Species 2017, e.T14328A113301882. Available online: http:/ / dx.doi.org/10.2305/IUCN.UK.2017-1.RLTS.T14328A113301882. en (accessed on 20 October 2017).

33. Németh, A.; Révay, T.; Hegyeli, Z.; Farkas, J.; Czabán, D.; Rózsás, A.; Csorba, G. Chromosomal forms and risk assessment of Nannospalax (superspecies leucodon) (Mammalia: Rodentia) in the Carpathian Basin. Folia Zool. 2009, 58, 349-361.

34. Csorba, G.; Krivek, G.; Sendula, T.; Homonnay, Z.G.; Hegyeli, Z.; Sugár, S.; Farkas, J.; Stojnić, N.; Németh, A. How can scientific researches change conservation priorities? A review of decade-long research on blind mole-rats (Rodentia: Spalacinae) in the Carpathian Basin. Therya 2015, 6, 103-121. [CrossRef]

35. Savić, I.; Nevo, E. The Spalacidae: Evolutionary history, speciation, and population biology. In Evolution of Subterranean Mammals at the Organismal and Molecular Levels; Nevo, E., Reig, O.A., Eds.; Alan R. Liss, Inc.: New York, NY, USA, 1990; pp. 129-153.

36. Nevo, E.; Ivanitskaya, E.; Beiles, A. Adaptive Radiation of Blind Subterranean Mole Rats: Naming and Revisiting the Four Siblingspecies of the Spalax ehrenbergi Superspecies in Israel: Spalax galili $(2 n=52)$, S. golani $(2 n=54)$, S. carmeli $(2 n=58)$ and S.judaei $(2 n=60)$; Bachkhuys Publishers: Leiden, The Netherlands, 2001.

37. Savić, I.; Soldatović, B. Contribution to the study of ecogeographic distribution and evolution of chromosomal forms of the Spalacidae from the Balkan Peninsula. Arch. Biol. Nauka 1977, 29, 141-156. (In Serbian)

38. Nevo, E. Mode, tempo, and pattern of evolution in subterranean mole rats of the Spalax ehrenbergi superspecies in the Quaternary of Israel. Quat. Int. 1993, 19, 13-19. [CrossRef]

39. Sözen, M.; Matur, F.; Çolak, E. Some karyological records and a new chromosomal form for Spalax (Mammalia: Rodentia) in Turkey. Folia Zool. 2006, 55, 247-256.

40. Kryštufek, B.; Vohralík, V. Mammals of Turkey and Cyprus. Rodentia II. Cricetinae, Muridae, Spalacidae, Calomyscidae, Capromyidae, Hystricidae, Castoridae; Knjižnica Annales Majora: Koper, Slovenia, 2009. 
41. De Bruijn, H. Remains of the mole rat Microspalax odessanus Topachevski from Karaburun (Greece, Makedonia) and the family Spalacidae. Proc. Koninkl. Ned. Akad. Wet. Ser. B 1984, 87, 417-425.

42. Németh, A.; Krnács, G.; Krizsik, V.; Révay, T.; Czabán, D.; Stojnić, N.; Farkas, J.; Csorba, G. European rodents on the edge: Status and distribution of the Vojvodina blind mole rat. Springerplus 2013, 2. [CrossRef] [PubMed]

43. Ünay, E. On fossil Spalacidae (Rodentia). In The evolution of Western Eurasian Neogene Mammal Faunas; Bernor, R.L., Fahlbush, V., Mittmann, H.W., Eds.; Columbia University Press: New York, NY, USA, 1996; pp. 246-252.

44. De Bruijn, H.; Bosma, A.A.; Wessels, W. Are the Rhizomyinae and the Spalacinae closely related? Contradistinctive conclusions between genetics and palaeontology. Palaeobio Palaeoenv. 2015, 95, 257-269. [CrossRef]

45. Bolliger, T. Family Anomalomyidae. In The Miocene Land Mammals of Europe; Rössner, G.E., Heissig, K., Eds.; Verlag Dr. Friederich Pfeil: München, Germany, 1999; pp. 389-394.

46. Şen, Ş.; Sarica, N. Middle-Late Miocene Spalacidae (Mammalia) from Western Anatolia, and the Phylogeny of the Family. Yerbilimleri 2011, 32, 21-50.

47. de Bruijn, H.; Marković, Z.; Wilma, W. Late Oligocene rodents from Banovići (Bosnia and Herzegovina). Palaeodiversity 2013, 6, 63-105.

48. De Bruijn, H. A new stage in the evolution of the mole rats (Rodentia, Spalacinae) from the Early Miocene of Northern Greece. Hist. Biol. 2017, 29, 571-575. [CrossRef]

49. Hofmeijer, K.G.; de Bruijn, H. The mammals from the Lower Miocene of Aliveri (Island of Evia, Greece). Part 4, The Spalacidae and Anomalomyidae. Proc. Koninkl. Ned. Akad. Wet.Ser. B. 1985, 88, 185-198.

50. Hadid, Y.; Németh, A.; Snir, S.; Pavlíček, T.; Csorba, G.; Kázmér, M.; Major, A.; Mezhzherin, S.; Rusin, M.; Coşkun, Y.; et al. Is evolution of blind mole rats determined by climate oscillations? PLoS ONE 2012, 7, e30043. [CrossRef] [PubMed]

51. Vorontsov, N.N.; Martynova, L.N.; Fomicheva, I.I. An electrophoretic comparison of the blood proteins in mole rats of the fauna of the USSR (Spalacinae, Rodentia). Zool. Zh. 1977, 56, 1207-1215. (In Russian)

52. Németh, A.; Homonnay, Z.G.; Krizsik, V.; Csorba, M.; Pavlíček, T.; Hegyeli, Z.; Hadid, Y.; Sugár, S.; Farkas, J.; Csorba, G. Old views and new insights: Taxonomic revision of the Bukovina blind mole rat, Spalax graecus (Rodentia: Spalacinae). Zool. J. Linn. Soc. 2013, 169, 903-914. [CrossRef]

53. Wahrman, J.; Goitein, R.; Nevo, E. Mole rat Spalax: Evolutionary significance of chromosome variation. Science 1969, 164, 82-84. [CrossRef] [PubMed]

54. Matthey, R. Formules chromosomiques de Muridae et de Spalacidae. La question du polymorphisme chromosomique chez les Mammifères. Rev. Suisse Zool. 1959, 66, 175-209. [CrossRef]

55. Walknowska, J. Les chromosomes chez Spalax leucodon Nordm. Folia Biol. (Kraków) 1963, 11, $30-48$.

56. Harrison, D.L.; Bates, P.J.J. The Mammals of Arabia; Harrison Zoological Museum: Kent, UK, 1991.

57. Nevo, E.; Filippucci, M.G.; Redi, C.; Simson, S.; Heth, G.; Beiles, A. Karyotype and genetic evolution in speciation of subterranean mole rats of the genus Spalax in Turkey. Biol. J. Linn. Soc. 1995, 54, 203-229. [CrossRef]

58. Nevo, E.; Filippucci, M.G.; Beiles, A. Genetic polymorphisms in subterranean mammals (Spalax ehrenbergi superspecies) in the Near East revisited: Patterns and theory. Heredity 1994, 72, 465-487. [CrossRef] [PubMed]

59. Arslan, A.; Zima, J. Karyotypes of the mammals of Turkey and neighboring regions: A review. Folia Zool. 2014, 63, 1-62. [CrossRef]

60. Savić, I.; Soldatović, B. Distribution range and evolution of chromosomal forms in the Spalacidae of the Balkan Peninsula and bordering regions. J. Biogeogr. 1979, 6, 363-374. [CrossRef]

61. Arslan, A.; Zima, J. Heterochromatin distribution and localization of NORs in the $2 \mathrm{n}=48$ cytotypes of Nannospalax xanthodon and N. ehrenbergi. Turk. J. Zool. 2017, 41, 390-396. [CrossRef]

62. Raicu, P.; Bratosin, S.; Hamar, M. Study on the karyotype of Spalax leucodon Nordm. and S. microphthalmus Güld. Caryologia 1968, 21, 127-135. [CrossRef]

63. Raicu, P.; Duma, D. Cytogenetical study in Sp. leucodon in Moldavia (Romania). Genet. Res. 1969, 13, 99-104. [CrossRef]

64. Peshev, D.T.; Vorontsov, N.N. Chromosomal variability in the mole rats Nannospalax leucodon Nordmann complex in Bulgaria. In Proceedings of the Third Intern. Theriological Congress Abstract Book, Helsinki, Finland, 1982; Myllymaki, A., Pulliainen, P., Eds.; p. 190. 
65. Kandemir, I.; Sözen, M.; Matur, F.; Kankılıç, T.; Martínková, N.; Çolak, F.; Özkurt, S.Ö.; Çolak, E. Phylogeny of species and cytotypes of mole rats (Spalacidae) in Turkey inferred from mitochondrial cytochrome $b$ sequences. Folia Zool. 2012, 61, 25-33.

66. Hausser, J.; Fedyk, S.; Fredga, K.; Searle, J.B.; Volobouev, V.; Woicik, J.M.; Zima, J. Definition and nomenclature of the chromosome races of Sorex araneus. Folia Zool. 1994, 43 (Suppl. I), 1-9.

67. Petrova, T.V.; Tesakov, A.S.; Kowalskaya, Y.M.; Abramson, N.I. Cryptic speciation in the narrow-headed vole, Lasiopodomys (Stenocranius) gregalis, (Rodentia: Cricetidae). Zool. Scr. 2016, 45, 618-629. [CrossRef]

68. Soldatović, B. Cytogenetic Study of the Speciation of the Genus Spalax in Yugoslavia. Ph.D. Thesis, University of Beograd, Belgrade, Serbia, 1971. (In Serbian)

69. Soldatović, B. Karyotype analysis and cytogenetic aspects of speciation in the genus Spalax. Zbornik Prir. Nauk. Mat. Srp. 1977, 52, 5-58. (In Serbian)

70. Soldatović, B.; Savić, I. New karyotype form of the mole rat (Spalax Güld.). Arch. Biol. Nauka 1973, 25, 13-14.

71. Savić, I.R.; Rempe, U. Vergleichende kraniometrische Untersuchungen über Vertrerer der Gattung Spalax (Microspalax) auf der Balkan-Halbinsel. Vortrag zur 51. In Proceedings of the Hauptversammlung der Deutschen Gesellschaft für Säugetierkunde, Bamberg, Germany, 18-23 September 1977.

72. Peshev, D. On the caryotypes in some populations of the mole rat (Spalax leucodon Nordmann) in Bulgaria. Zool. Anz. 1981, 206, 129-131.

73. Sözen, M. A karyological study on subterranean mole rats of the Spalax leucodon Nordmann, 1840 superspecies in Turkey. Mamm. Biol. 2004, 64, 420-429. [CrossRef]

74. Sözen, M.; Çolak, F.; Sevindik, M.; Matur, F. Cytotypes of Nannospalax xanthodon (Satunin, 1898) (Rodentia, Spalacidae) from western Anatolia. Turk. J. Zool. 2013, 37, 462-469. [CrossRef]

75. Kankılıç, T.; Kankılıç, T.; Sözen, M.; Çolak, E. Genetic Diversity and Geographic Variation of Chromosomal races of Nannospalax xanthodon (Nordmann, 1840) and Nannospalax ehrenbergi (Nehring, 1898) from Turkey, Revealed by RAPD Analysis. Acta Zool. Bulg. 2013, 65, 45-58.

76. Coşkun, Y.; Ulutürk, S.; Kaya, A. Karyotypes of Nannospalax (Palmer 1903) populations (Rodentia: Spalacidae) from centraleastern Anatolia, Turkey. Hystrix 2010, 21, 89-96.

77. Ivanitskaya, E.; Rashkovetsky, L.; Nevo, E. Chromosomes in a hybrid zone of Israeli mole rats (Spalax, Rodentia). Russ. J. Genet. 2010, 46, 1149-1151. [CrossRef]

78. Nevo, E.; Bar-El, H. Hybridization and speciation in fossorial mole rats. Evolution 1976, 30, 831-840. [CrossRef] [PubMed]

79. Ivanitskaya, E.; Coskun, Y.; Nevo, E. Banded karyotypes of mole rats (Spalax, Spalacidae, Rodentia) from Turkey. J. Zool. Syst. Evol. Res. 1997, 35, 171-177. [CrossRef]

80. Ivanitskaya, E.; Sözen, M.; Rashkovetsky, L.; Matur, F.; Nevo, F. Discrimination of $2 \mathrm{n}=60$ Spalax leucodon cytotypes (Spalacidae, Rodentia) in Turkey by means of classical and molecular cytogenetic techniques. Cytogenet. Genome Res. 2008, 122, 139-149. [CrossRef] [PubMed]

81. Matur, F.; Çolak, F.; Ceylan, T.; Sevindik, M.; Sözen, M. Chromosomal evolution of the genus Nannospalax (Palmer 1903) (Rodentia, Muridae) from western Turkey. Turk. J. Zool. 2013, 37, 470-487. [CrossRef]

82. Arslan, A.; Akan, Ş.; Zima, J. Variation in C-heterochromatin and NORs distribution among chromosomal races of mole rats (Spalacidae) from Central Anatolia, Turkey. Mamm. Biol. 2011, 76, 28-35. [CrossRef]

83. Nevo, E.; Ivanitskaya, E.; Filippucci, M.G.; Beiles, A. Speciation and adaptive radiation of subterranean mole rats, Spalax ehrenbergi superspecies, in Jordan. Biol. J. Linn. Soc. 2000, 69, 263-281. [CrossRef]

84. Matur, F.; Çolak, F.; Sevindik, M.; Sözen, M. Chromosome differentiation of four $2 \mathrm{n}=50$ chromosomal forms of Turkish mole rat. Nannospalax nehringi. Zool. Sci. 2011, 28, 61-67. [CrossRef] [PubMed]

85. Ivanitskaya, E.; Belyayev, A.; Nevo, E. Heterochromatin differentiation shows the pathways of karyotypic evolution in Israeli mole rats (Spalax, Spalacidae, Rodentia). Cytogenet. Genome Res. 2005, 111, 159-165. [CrossRef] [PubMed]

86. Zima, J.; Macholán, M.; Kryštufek, B.; Petkovski, S. Karyotypes of certain small mammals (Insectivora, Rodentia) from Makedonia. Scopolia 1997, 38, 1-15.

87. Savic, I.R. Diversification of the Balkan fauna: Its origin, historical development and present status. In Advances in Arachnology and Developmental Biology Papers Dedicated to Prof. Dr. Božidar Ćurčić; Makarov, S.E., Dimitrijević, R.N., Eds.; Inst. Zool.: Belgrade, Serbia; BAS: Sofia, Belgrade; Fac. Life Sci.: Vienna, Austria; SASA: Belgrade, Serbia; UNESCO MAB: Belgrade, Serbia, 2008; Volume 12, pp. 57-78. 
88. Arslan, E.; Gülbahçe, E.; Arıkoğlu, H.; Arslan, A.; Bužan, E.; Kryštufek, B. Mitochondrial divergence between three cytotypes of the Anatolian mole rat, Nannospalax xanthodon (Nordmann, 1849). Zool. Middle East 2010, 50, 27-34. [CrossRef]

89. Reyes, A.; Nevo, E.; Saccone, C. DNA sequence variation in the mitochondrial control region of subterranean mole rats, Spalax ehrenbergi superspecies, in Israel. Mol. Biol. Evol. 2003, 20, 622-632. [CrossRef] [PubMed]

90. Yüksel, E.; Gülkaç, M.D. On the karyotypes of some populations of the subterranean mole rats in the lower Euphrates basin, Turkey. Caryologia 1992, 45, 175-190. [CrossRef]

91. Catzeflis, F.M.; Nevo, E.; Ahlquist, J.E.; Sibley, C. Relationships of the chromosomal species in the Eurasian mole rats of the Spalax ehrenbergi group as determined by DNA-DNA hybridization and an estimate of the spalacid-murid divergence time. J.Mol. Evol. 1989, 29, 223-232. [CrossRef] [PubMed]

92. Nižetić, D.; Stevanović, M.; Soldatović, B.; Savić, I.; Crkvenjakov, R. Limited polymorphism of both classes of MHC genes in four different species of the Balkan mole rat. Immunogenetics 1988, 28, 91-98. [CrossRef] [PubMed]

93. Nevo, E. Molecular evolution and environmental stress. In Gene Families: Studies of DNA, RNA, Enzymes and Proteins; Xue, G., Xue, Y., Xu, Z., Holmes, R., Hammond, L., Lim, H.A., Eds.; World Scientific Pub. Co.: Singapore, 2001; pp. 73-87.

94. Avise, J.C. Phylogeography: The History and Formation of Species; Harvard University Press: Cambridge, UK, 2000.

95. Karanth, K.P.; Avivi, A.; Beharav, A.; Nevo, E. Microsatellite diversity in populations of blind subterranean mole rats (Spalax ehrenbergi superspecies) in Israel: Speciation and adaptation. Biol. J. Linn. Soc. 2004, 83, 229-241. [CrossRef]

96. Nevo, E.; Beiles, A.; Spradling, T. Molecular evolution of cytochrome $b$ of subterranean mole rats, Spalax ehrenbergi superspecies, in Israel. J. Mol. Evol. 1999, 49, 215-226. [CrossRef] [PubMed]

97. White, T.A.; Bordewich, M.; Searl, J.B. A network approach to study karyotypic evolution: The chromosomal races of the common shrew (Sorex araneus) and house mouse (Mus musculus) as model systems. Syst. Biol. 2010, 59, 262-276. [CrossRef] [PubMed]

98. Wójcik, J.M.; Borodin, P.M.; Fedyk, S.; Fredga, K.; Hausser, J.; Mishta, A.; Orlov, V.N.; Searle, J.B.; Volobouev, V.T.; Zima, J. The list of the chromosome races of the common shrew Sorex araneus (updated 2002): The International Sorex araneus Cytogenetics Committee (ISACC). Mammalia 2003, 67, 169-178. [CrossRef]

99. Piálek, J.; Hauffe, H.C.; Searle, J.B. Chromosomal variation in the house mouse. Biol. J. Linn. Soc. 2005, 84, 535-563. [CrossRef]

100. Nevo, E.; Beiles, A. Ribosomal DNA nontranscribed spacer polymorphism in subterranean mole rats: Genetic differentiation, environmental correlates, and phylogenetic relationships. Evol. Ecol. 1988, 2, 139-156. [CrossRef]

101. Kankılıç, T.; Gürpınar, C. Revised classification design of the Anatolian species of Nannospalax (Rodentia: Spalacidae) using RFLP analysis. Turk. J. Zool. 2014, 38, 68-78. [CrossRef]

102. Kankılıç, T.; Kankılıç, T.; Şeker, P.S.O.; Kıvanç, E. Morphological and biometrical comparisons of the baculum in the genus Nannospalax Palmer, 1903 (Rodentia: Spalacidae) from Turkey with consideration of its taxonomic importance. Turk. J. Zool. 2014, 38, 144-157. [CrossRef]

103. Dobzhansky, T.; Epling, C. Contribution to the Genetics, Taxonomy and Ecology of Drosophila pseudoobscura and Its Relatives; Carnegie Institution of Washington: Washington, DC, USA, 1944; Volume 544, pp. 1-46.

104. Mayr, E. Artbegriff und Evolution; Verlag Paul Parey: Hamburg/Berlin, Germany, 1967; p. 617.

105. Orr, H.A. Dobzhansky, Bateson and the genetics of speciation. Genetics 1996, 144, 1331-1335. [PubMed]

106. White, M.J.D. Modes of Speciation; WH Freeman: San Francisco, CA, USA, 1978.

107. Navarro, A.; Barton, N.H. Chromosomal speciation and molecular divergence-accelerated evolution in rearranged chromosomes. Science 2003, 300, 321-324. [CrossRef] [PubMed]

108. Dobzhansky, T. The Y chromosome of Drosophila pseudoobscura. Genetics 1935, 20, 366-376. [PubMed]

109. Bush, G.L.; Case, S.M.; Wilson, A.C.; Patton, J.L. Rapid speciation and chromosomal evolution in mammals. Proc. Nat. Acad. Sci. USA 1977, 74, 3942-3946. [CrossRef] [PubMed]

110. Searle, J.B. Chromosomal hybrid zones in eutherian mammals. In Hybrid Zones and the Evolutionary Process; Harrison, R.G., Ed.; Oxford University Press: Oxford, UK, 1993; pp. 309-353.

111. Sözen, M.; Çolak, E.; Yiğit, N.; Ozkurt, Ş.; Verimli, R. Contributions to the karyology and taxonomy of the genus Spalax Güldenstaedt, 1770 (Mammalia: Rodentia) in Turkey. Z. Säugetierkd. 1999, 64, 210-219. 
112. Golenishchev, F.N.; Meyer, M.N.; Bulatova, N.S. The hybrid zone between two karyomorphs of Microtus arvalis (Rodentia, Arvicolinae). Proc. Zool. Inst. Russ. Acad. Sci. 2001, 289, 89-94.

113. Kovalskaya, Y.M.; Savinetskaya, L.E.; Aksenova, T.G. Experimental Hybridization of Voles of the Genus Microtus s.l. M. socialis with Species of the Group arvalis (Mammalia, Rodentia). Biol. Bull. 2014, 41, 559-563. [CrossRef]

114. Bickford, D.; Lohman, D.J.; Sodhi, N.S.; Peter, K.L.N.; Meier, R.; Winker, K.; Ingram, K.K.; Das, I. Cryptic species as a window on diversity and conservation. Trends Ecol. Evol. 2006, 22. [CrossRef] [PubMed]

115. Faria, R.; Navarro, A. Chromosomal speciation revisited: Rearranging theory with pieces of evidence. Trends Ecol. Evol. 2010, 25. [CrossRef] [PubMed]

116. Cvijić, J. Die Tektonik der Balkanhalbinsel; Comptes Rendus, IX Congrès International de Géographie de la France: Paris, France, 1904; Volume 5, pp. 247-254.

117. Yang, F.; Carter, N.P.; Shi, L.; Ferguson-Smith, M.A. A comparative study of karyotypes of muntjacs by chromosome painting. Chromosoma 1995, 103, 642-652. [CrossRef] [PubMed]

118. Peshev, D. Craniological study of the species of the genus Spalax (Spalacidae, Mammalia) I. Sex Dimophism. Zool. Anz. 1989, 222, 83-91.

119. Nevo, E.; Shaw, C.R. Genetic variation in a subterranean mammal, Spalax ehrenbergi. Biochem. Genet. 1972, 7, 235-241. [CrossRef] [PubMed]

120. Yang, F.; O'Brien, P.C.; Weinbnerg, J.; Ferguson-Smith, M.A. A reappraisal of the tandem fusion theory of karyotype evolution in the Indian muntjac using chromosome painting. Chromosome Res. 1997, 5, 109-117. [CrossRef] [PubMed]

121. Ma, K.; Qiu, L.; Mrasek, K.; Zhang, J.; Liehr, T.; Quintana, L.G.; Li, Z. Common Fragile Sites: Genomic Hotspots of DNA Damage and Carcinogenesis. Int. J. Mol. Sci. 2012, 13, 11974-11999. [CrossRef] [PubMed]

122. Ruiz-Herrera, A.; Castresana, J.; Robinson, T.J. Is mammalian chromosomal evolution driven by regions of genome fragility? Genome Biol. 2006, 7, R115. [CrossRef] [PubMed]

123. Ferguson-Smith, M.A.; Yang, F.; O'Brien, P.C. Comparative mapping using chromosome sorting and painting. ILAR J. 1998, 39, 68-76. [CrossRef] [PubMed]

124. Stanyon, R.; Yang, F.; Cavagne, P.; O’Brien, P.C.M.; Bagga, M.; Ferguson-Smith, M.A.; Wienberg, J. Reciprocal chromosome painting shows that genomic rearrangement between rat and mouse proceeds ten times faster than between humans and cats. Cytogenet. Cell Genet. 1999, 84, 150-155. [CrossRef] [PubMed]

125. Matsubara, K.; Nishida-Umehara, C.; Kuroiwa, A.; Tsuchiya, K.; Matsuda, Y. Identification of chromosome rearrangements between the laboratory mouse (Mus musculus) and the Indian spiny mouse (Mus platythrix) by comparative FISH analysis. Chromosome Res. 2003, 11, 57-64. [CrossRef] [PubMed]

126. Deuve, J.L.; Bennett, N.C.; Britton-Davidian, J.; Robinson, T.J. Chromosomal phylogeny and evolution of the African mole-rats (Bathyergidae). Chromosome Res. 2008, 16, 57-74. [CrossRef] [PubMed]

127. Liehr, T.; Starke, H.; Heller, A.; Kosyakova, N.; Mrasek, K.; Gross, M.; Karst, C.; Steinhaeuser, U.; Hunstig, F.; Fickelscher, I.; et al. Multicolor fluorescence in situ hybridization (FISH) applied to FISH-banding. Cytogenet. Genome Res. 2006, 114, 240-244. [CrossRef] [PubMed]

128. Liehr, T.; Heller, A.; Starke, H.; Claussen, U. FISH banding methods: Applications in research and diagnostics. Expert. Rev. Mol. Diagn. 2002, 2, 217-225. [CrossRef] [PubMed]

129. Weise, A.; Mrasek, K.; Fickelscher, I.; Claussen, U.; Cheung, S.W.; Cai, W.W.; Liehr, T.; Kosyakova, N. Molecular Definition of High-resolution Multicolor Banding Probes: First Within the Human DNA Sequence Anchored FISH Banding Probe Set. J. Histochem. Cytochem. 2008, 56, 487-493. [CrossRef] [PubMed]

(C) 2017 by the authors. Licensee MDPI, Basel, Switzerland. This article is an open access article distributed under the terms and conditions of the Creative Commons Attribution (CC BY) license (http://creativecommons.org/licenses/by/4.0/). 